\title{
Impact of the corporate governance characteristics and ownership on earnings quality of the Islamic private banks in Iran
}

\author{
Mohammad Khodaei Valahzaghard $^{\mathrm{a}^{*}}$ and Ali Salehi ${ }^{\mathrm{b}}$
}

\author{
${ }^{a}$ Assist. Prof. \& Faculty Member, Department of Accounting, School of Management and Human Sciences, Tehran North Branch, Islamic Azad \\ University (IAU), Tehran, Iran \\ ${ }^{b}$ M.A. Student, Department of Accounting, School of Management, U.A.E. Branch, Islamic Azad University (IAU), Iran

\section{A R T I C L E I N F O} \\ Article history: \\ Received April 20, 2012 \\ Received in Revised form \\ June, 12, 2012 \\ Accepted 29 June 2012 \\ Available online \\ July 22012 \\ Keywords: \\ Quality of earnings \\ Corporate governance \\ Ownership \\ Private banks

\section{A B S T R A C T}

\begin{abstract}
This paper investigates corporate governance and ownership effects on earning quality in Iranian private banks. The study uses the information of 12 private banks from year 2005 to 2010 using regression analysis based on panel data. Among different factors, the effect of big five shareholder are considered to be significant and positive on earning quality. In addition, the effect of one variable regression test reveals that institutional ownership has positive impact on earning quality. However, the impacts of other variables including percentage of ownership concentration, the size of board of directors, reliance on debt, logarithm of sum of assets, return of assets, logarithm of operating cash flow on earning quality are not meaningful. The result of this survey indicates that institutional ownership plays an important role earning quality simply because institutions normally have the access on professionals to control management.
\end{abstract}

C) 2012 Growing Science Ltd. All rights reserved.

\section{Introduction}

Today, accounting profitability and its components play important role on making important decisions by shareholders, new investors, Taxing department, etc. Profit calculation is influenced by many methods and it can be manipulated so that it would create misleading results. There are always some reasons to have different numbers between actual and formal statements such as lack of good prediction for future events, applying different accounting methods, etc. Several empirical studies indicated that poor earnings quality could lead to increase in information risk and eventually it could increase the cost of equity (Francis et al., 2004). Since profit is the most important components of business evaluation, quality of earning has become the most important subject of research for the past few years. 
When earning quality increases, the changes of having manipulated statements will be reduced and corporate governance is one of the ways of reducing the risk of market manipulation. Corporate governance is described as the system in which companies are directed and controlled and it includes regulatory and market mechanisms (Ball \& Shivakumar, 2008). The roles and relationships between a company's management, its board, its shareholders and other stakeholders, and the objectives for which the corporation is governed. In many business units, the main external stakeholder groups are shareholders, trade creditors, debt holders, suppliers, customers and communities influenced by the corporation's activities. Internal stakeholders are the board of directors, executives, and other employees (Haidar, 2009).

During the past decades, there have been different cases of financial corruption such as Enron, which created a bad image for many well know accounting systems (Dechow \& Shrand, 2004; Scott et al., 2005; Dechow et al., 2009; Huang et al., 2009). Cain et al. (2009) performed a comprehensive survey of the use of income-decreasing special items to manage earnings. They reported that low-quality special items violate the concept of a transitory item, as they were associated with future operating cash flows, while high-quality special items were not. They also reported that low-quality special items could predict accounting restatements, while high-quality special items do not.

Ashbaugh-Skaife et al. (2007) reported that firms with material internal control weaknesses are smaller and they have more complex operations, greater accounting risk, and weaker financial performance, Dechow and Ge (2005) suggested that the applicable accounting rules influenced in accruals differ for firms increasing or reducing their asset bases and that this has implications for earnings persistence. Francis and Smith (2005) reexamined prior studies' conclusion that accruals are less persistent than cash, focusing on two effects of persistence that are important for determining its properties. The first, which is time specificity is associated with the fact that persistence describes how "current-period" shocks to income translate into next-period income.

They demonstrated that the inclusion of non-current-period transactions could lead to a downward bias on the persistence of cash flows. They also developed alternative measures of accruals and cash flows, which were not misaligned and showed that the differential persistence of cash flows over accruals was more than $70 \%$ smaller using these measures. They also evaluated persistence using firm-specific estimations and reported that more than $85 \%$ of firms had no evidence that accruals are less persistent than cash flows.

Bozec and Laurin (2008) discussed that the largest publicly traded companies throughout the world had concentrated ownership especially the ones in Canada where voting rights are often concentrated in the hands of large shareholders, mostly wealthy families. Such concentrated ownership structures can create specific agency problems, such as large shareholders expropriating wealth from minority shareholders. Bozec and Laurin (2008) evaluated the effect of separation on various performance metrics while controlling for situations when the large shareholder had the chance to expropriate and the incentive to expropriate.

\section{The proposed model}

This paper investigates corporate governance and ownership effects on earning quality in Iranian private banks. The study uses the information of 12 private banks from year 2005 to 2010 using regression analysis based on panel data. We use standard measures to extract the needed figures in all our investigations. 


\subsection{Independent and dependent variables}

As explained earlier, earning quality is the primary dependent variable of the proposed study and it is calculated using David Hawkins index as follows,

Earning quality $=\frac{\text { Earning before Tax }+ \text { Interest costs }}{\text { Total assetes }- \text { current liabilities }}$.

When this ratio is high, it means that earning quality is high and when it is in its low level, it means the quality of earning is low. Institutional ownership is the first independent variable of this research and it refers to the ownership stake in a company held by large financial organizations, pension funds or endowments. Institutions generally make a big acquisition in forms of blocks of a company's outstanding shares and can exert considerable impact on its management.

Examples of institutional owners include college endowments, corporate pension funds, commercial banks, insurance companies, hedge funds, mutual funds, etc., which invest money for wealthy clients. The other independent variable is ownership concentration, which can be calculated using the Herfindahl index or Herfindahl-Hirschman Index (HHI), which is a measure of the size of firms in association with the industry and an indicator of the amount of competition among them. In United State, HHI is a mathematical calculation, which uses market-share figures to figure out whether a proposed merger is challenged by the government.

The HHI is calculated by squaring the market share of each merging firm competing in the market and then adding the results. For instance, if four merging firms have market shares of 25 percent, 25 percent, 30 percent, and 20 percent, the HHI is $2,550\left(25^{2}+25^{2}+30^{2}+20^{2}=2,550\right)$. The HHI considers the relative size and distribution of the firms in a market and approaches zero when a market consists of a large number of firms, all of which are in small portions of ownership. Another ratio is calculated based on HHI index and it shows the percentage of the five biggest shareholders. This ratio simply shows the relative ownership of the biggest shareholders and it is calculated as follows,

Five biggest shareholder position $(\%)=\frac{\text { Five biggest shareholder position }}{100 \text {-Five biggest shareholder position }}$.

The size of the banks is another important ratio calculated by taking a natural logarithm on total assets. In addition, the numbers of board of directors as well as debt ratio (total liabilities /total assets) are two other variables used for the proposed study of this paper. Finally, cash flow from operating programs and return of assets are the last variables of the proposed model of this paper and the mathematical model is as follows,

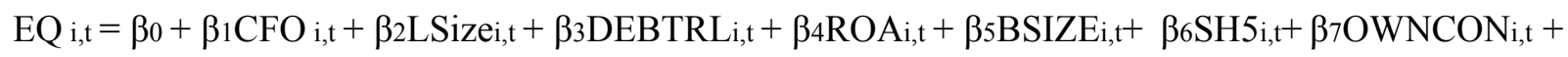
$\beta 8 \mathrm{INSOWNi,t}++\varepsilon \mathrm{i}, \mathrm{t}$,

where EQ represents earning quality, CFO is the operational cash flow, LSIE is the size of bank, DEBTRL is the debt ratio, ROA is the return on assets, $\mathrm{SH} 5$ is the percentage of five big shareholders and OWNCON is the consolidated ownership, respectively.

\section{Data analysis and results}

In this paper, we first present details of the data in terms of basic statistical observation. Table 1 shows some of the statistical measures such as mean, skewness and strain for the survey. 


\section{Table 1}

Financial characteristics of banks for 72 observations

\begin{tabular}{lccccccc}
\hline & & & & & \multicolumn{2}{c}{ Deviation } \\
Var. & Mean & Standard deviation & Variance & Skewness & Strain & Skewness & Strain \\
\hline EQ & 0.030 & 0.017 & 0.000 & 1.261 & 3.100 & 4.459 & 5.547 \\
INSOWN & 64.104 & 20.322 & 412.984 & -0.107 & -0.534 & -0.378 & -0.955 \\
SH5 & 2.517 & 4.162 & 17.320 & 2.771 & 7.535 & 9.796 & 13.483 \\
OWNCON & 2.779 & 0.538 & 0.289 & 0.033 & -0.540 & 0.116 & -0.967 \\
BSIZE & 5.444 & 1.564 & 2.448 & 0.719 & 0.189 & 2.541 & 0.337 \\
DEBTRL & 0.883 & 0.242 & 0.058 & -1.852 & 9.065 & -6.548 & 16.222 \\
Lsize & 4.735 & 0.657 & 0.432 & -0.001 & -1.139 & -0.004 & -2.038 \\
ROA & 0.019 & 0.014 & 0.000 & 1.409 & 2.864 & 4.980 & 5.124 \\
CFO & 5.462 & 2.123 & 4.508 & -1.492 & 0.584 & -5.274 & 1.044 \\
\hline
\end{tabular}

One of other non-parametric assumptions of using non-parametric test is the normality of variables. In order to test normality we use Kolmogorov-Smirnov, Shapiro-Wilk and Jarque- bera tests. The level of significance is small for the first two tests which means the variables are not normally distributed and based on the last test distribution of bank size is normal and others are not. Table 2 shows details of the results.

\section{Table 2}

Normality test using three methods

\begin{tabular}{lccccccc}
\hline & & \multicolumn{2}{c}{ Kolmogorov-Smirnov } & \multicolumn{2}{c}{ Shapiro-Wilk } & \multicolumn{2}{c}{ Jarque- bera } \\
\hline Variable & Number & $\mathrm{k}-\mathrm{s}$ & Sig & s-w & Sig & j-b & Sig \\
\hline EQ & 72 & .122 & .010 & .922 & .000 & 41.93011 & 0.000000 \\
INSOWN & 72 & .195 & .000 & .896 & .000 & 1.139991 & 0.565528 \\
SH5 & 72 & .332 & .000 & .557 & .000 & 232.8017 & 0.000000 \\
OWNCON & 72 & .167 & .000 & .949 & .006 & 1.042034 & 0.593916 \\
BSIZE & 72 & .251 & .000 & .896 & .000 & 5.968129 & 0.050587 \\
DEBTRL & 72 & .326 & .000 & .555 & .000 & 249.4125 & 0.000000 \\
Lsize & 72 & .095 & .180 & .960 & .021 & 3.921473 & 0.140755 \\
ROA & 72 & .138 & .002 & .889 & .000 & 42.89160 & 0.000000 \\
CFO & 72 & .307 & .000 & .683 & .000 & 26.24061 & 0.000002 \\
\hline
\end{tabular}

\subsection{Chow and Hausman test}

Since we deal with multi variable regression analysis, we need to determine the status of regression intercepts and slops of banks. In order to use unique or different intercepts we use Chow test. When all intercept are equal we use pooled method, otherwise we use panel method. According to Hausman test (Davidson \& MacKinnon, 1993), if random effects are rejected we use fixed effect, otherwise we use random effect. The results of Chow test implies that we should use panel method and Hausman method recommends fixed effect.

There are ten models associated with the proposed study of this paper. In our study, there are eight independent variables and one dependent variable. In the first model, we only consider the relationship between dependent and independent variables while in the second model, four control variables are considered in addition to independent variables. From model three to model ten, we consider the relationship between each independent variable and dependent variable. Table 3 shows details of our tests.

The other primary assumption of all parametric tests is to have linear relationship between independent variables and dependent variable and F-statistic confirms this issue. In other words, the level of significance indicates that there is a linear relationship between independent variables of dependent variable. 
Table 3

The results of Haman and Chow tests

\begin{tabular}{|c|c|c|c|c|c|c|c|}
\hline \multirow{2}{*}{$\begin{array}{l}\text { Model } \\
\text { hypothesis }\end{array}$} & \multirow{2}{*}{$\begin{array}{l}\text { Test } \\
\text { specification }\end{array}$} & \multicolumn{3}{|c|}{ Chow test } & \multicolumn{3}{|c|}{ Hausman Test } \\
\hline & & $\mathrm{F}$ & Error & Result & $\chi$ & Error & Result \\
\hline \multirow{3}{*}{ First } & Pooled & 1.828962 & 0.1202 & Equal intercept & & & \\
\hline & Panel & 6.921006 & 0.0000 & Unequal slop & 5.317936 & 0.2562 & Random effects \\
\hline & Pooled & 1.870539 & 0.1135 & Unequal intercept & & & \\
\hline \multirow[t]{2}{*}{ Second } & Panel & 7.012344 & 0.0000 & Unequal slop & 3.625540 & 0.8892 & Random effects \\
\hline & Pooled & 1.605800 & 0.1710 & Unequal intercept & & & \\
\hline \multirow[t]{2}{*}{ Third } & Panel & 8.050765 & 0.0000 & Unequal slop & 5.540226 & 0.0186 & Fixed effect \\
\hline & Pooled & 1.260834 & 0.2916 & Unequal intercept & & & \\
\hline \multirow[t]{2}{*}{ Fourth } & Panel & 7.770808 & 0.0000 & Unequal slop & 1.388522 & 0.2387 & Random effects \\
\hline & Pooled & 1.412773 & 0.2314 & Unequal intercept & & & \\
\hline \multirow[t]{2}{*}{ Fifth } & Panel & 6.887023 & 0.0000 & Unequal slop & 2.575679 & 0.1085 & Random effects \\
\hline & Pooled & 1.454540 & 0.2169 & Unequal intercept & & & \\
\hline \multirow[t]{2}{*}{ Sixth } & Panel & 6.314875 & 0.0000 & Unequal slop & 1.543587 & 0.2141 & Random effects \\
\hline & Pooled & 1.424378 & 0.2273 & Unequal intercept & & & \\
\hline \multirow[t]{2}{*}{ Seventh } & Panel & 6.663895 & 0.0000 & Unequal slop & 1.063468 & 0.3024 & Random effects \\
\hline & Pooled & 2.869027 & 0.0211 & Unequal intercept & 12.509733 & 0.0004 & Fixed effect \\
\hline \multirow[t]{2}{*}{ Eighths } & Panel & 1.260834 & 0.2916 & Unequal slop & & & \\
\hline & Pooled & 1.392679 & 0.2387 & Unequal intercept & & & \\
\hline \multirow[t]{2}{*}{ Ninth } & Panel & 6.482839 & 0.0000 & Unequal slop & 0.242966 & 0.6221 & Random effects \\
\hline & Pooled & 1.441765 & 0.2213 & Unequal intercept & & & \\
\hline Tenth & Panel & 6.595095 & 0.0000 & Unequal slop & 1.714200 & 0.1904 & Random effects \\
\hline
\end{tabular}

Another test is to see whether residuals are normality distributed or not and Table 4 shows details of our survey. As we can observe from the results of Table 4, we cannot claim that residuals are normally distributed according to Jarque-bera test when the level of significance is five percent. The other test for the survey is to see whether there is any correlation between residual and Durbin Watson (DW) test is one of the most popular tests to verify this issue. As we can observe from the results, all DW tests are located within acceptable limit, which means there is no correlation among residuals.

\section{Table 4}

The results of different statistics

\begin{tabular}{lccccc}
\hline Model & \multicolumn{2}{c}{ Linear relationship } & Durbin Watson test & \multicolumn{2}{c}{ Residual } \\
\cline { 2 - 6 } & F & Sig. & D.W. & J B statistics & Sig. \\
\hline 1 & 3.025939 & 0.035388 & 1.544584 & 42.95680 & 0.000000 \\
2 & 2.451696 & 0.022301 & 1.796383 & 39.94081 & 0.000000 \\
3 & 7.392181 & 0.000000 & 1.652250 & 21.71443 & 0.000019 \\
4 & 8.924606 & 0.003877 & 1.536354 & 57.07312 & 0.000000 \\
5 & 1.551419 & 0.217079 & 1.218940 & 38.88551 & 0.000000 \\
6 & 0.713866 & 0.401042 & 1.214959 & 22.41433 & 0.000000 \\
7 & 2.120883 & 0.149774 & 1.258913 & 35.04564 & 0.000000 \\
8 & 3.707146 & 0.058243 & 0.687745 & 28.97852 & 0.000001 \\
9 & 4.683658 & 0.033864 & 1.331278 & 83.03802 & 0.000000 \\
10 & 1.736449 & 0.191886 & 1.327395 & 38.64864 & 0.000000 \\
\hline
\end{tabular}

In terms of having linear relationships between the dependent variable and independent variables, Fstatistics is statistically significant only for four models when the level of significance is set to five percent. All Durbin Watson values are statistically meaningful for the four models, which mean they are located within the acceptable limits.

Finally, none of J_B values means that the distributions of all ten models are not normally distributed. However, by drawing the distribution we can figure out that the distributions are close to normal. One 
final step is to find out whether there is any strong correlation among independent variables and Table 5 shows details of our findings,

Table 5

The results of Pearson correlation test

\begin{tabular}{cccccccccc}
\hline & INSOWN & SH5 & OWNCON & BSIZE & DEBTRL & Lsize & ROA & CFO \\
\hline INSOWN & 1 & .622 & .511 & -.491 & .154 & .397 & -.204 & .074 \\
SH5 & .622 & 1 & .533 & -.293 & .163 & -.048 & .125 & -.033 \\
OWNCON & .511 & .533 & 1 & -.510 & -.031 & -.123 & .000 & -.253 \\
BSIZE & -.491 & -.293 & -.510 & 1 & -.017 & .043 & .430 & .182 \\
DEBTRL & .154 & .163 & -.031 & -.017 & 1 & .339 & -.226 & .029 \\
Lsize & .397 & -.048 & -.123 & .043 & .339 & 1 & -.462 & .254 \\
ROA & -.204 & .125 & .000 & .430 & -.226 & -.462 & 1 & .118 \\
CFO & .074 & SH5 & -.253 & .182 & .029 & .254 & .118 & 1 \\
\hline
\end{tabular}

As we can observe from the results of Table 5, there is no strong correlation among independent variables so that we can make a conclusion that there is co-linearity between variables.

\section{Table 6}

The results of the first regression model

\begin{tabular}{lccccc}
\hline & & Coefficient & Standard deviation & t-student & P-value \\
\hline$\beta_{0}$ & C & 0.037443 & 0.033487 & 1.118130 & 0.2675 \\
$\beta_{1}$ & INSOWN & 0.000054 & 0.000144 & 0.370825 & 0.7119 \\
$\beta_{2}$ & SH5 & 0.001271 & 0.000632 & 2.012396 & 0.0482 \\
$\beta_{3}$ & OWNCON & -0.003537 & 0.007963 & -0.444208 & 0.6583 \\
$\beta_{4}$ & BSIZE & -0.000729 & 0.002649 & -0.275185 & 0.7840 \\
\hline
\end{tabular}

$\mathrm{R}^{2}=0.117, \mathrm{AdR}^{2}=0.064, \mathrm{~F}=3.025, \mathrm{D} . \mathrm{W}=1.87$, S.E.of regression $=0.0116$, Sum squared resid $=0.0090$ $\mathrm{EQ}=0.0374+0.000054 * \mathrm{INSOWN}+0.00127 * \mathrm{SH} 5-0.00353 * \mathrm{OWNCON}-0.00072 * \mathrm{BSIZE}+[\mathrm{CX}=\mathrm{R}]$

As we can observe from the results of Table 6, statistical observations indicate that only the effect of five big shareholders is statistically meaningful, which means that institutional ownership, ownership concentration and the size of board of directors do not have any impact on earning quality.

Table 7

The results of the second regression model

\begin{tabular}{|c|c|c|c|c|c|}
\hline & & Coefficient & Standard deviation & t-student & P-value \\
\hline$\beta_{0}$ & $\mathrm{C}$ & 0.013455 & 0.049367 & 0.272543 & 0.7861 \\
\hline$\beta_{1}$ & INSOWN & 0.000057 & 0.000157 & 0.363254 & 0.7176 \\
\hline$\beta_{2}$ & SH5 & 0.001048 & 0.000470 & 2.229947 & 0.0293 \\
\hline$\beta_{3}$ & OWNCON & -0.003713 & 0.007821 & -0.474733 & 0.6366 \\
\hline$\beta_{4}$ & BSIZE & -0.001950 & 0.004390 & -0.444312 & 0.6583 \\
\hline$\beta_{5}$ & DEBTRL & 0.011916 & 0.009271 & 1.285337 & 0.2034 \\
\hline$\beta_{6}$ & Lsize & 0.002656 & 0.004922 & 0.539646 & 0.5913 \\
\hline$\beta_{7}$ & ROA & 0.317248 & 0.246036 & 1.289437 & 0.2020 \\
\hline$\beta_{8}$ & $\mathrm{CFO}$ & 0.000409 & 0.000754 & 0.542503 & 0.5894 \\
\hline \multicolumn{6}{|c|}{$\mathrm{R}^{2}=0.237, \mathrm{AdR}^{2}=0.140, \mathrm{~F}=2.451, \mathrm{D} . \mathrm{V}=1.79$, S.E.of regression $=0.0107$, Sum squared resid $=0.0073$} \\
\hline \multicolumn{6}{|c|}{$\mathrm{EQ}=0.0134+0.000057 * \mathrm{INSOWN}+0.00104 * \mathrm{SH} 5-0.0037 * \mathrm{OWNCON}-$} \\
\hline
\end{tabular}

As we can observe from the results of the second regression model, only the variable associated with five big shareholders is statistically meaningful and only when the level of significance is set to five percent.

In Table 8, we present details of our regression analysis from model three to model ten. 
Table 8

The results of regression function 8 simple regression analysis

\begin{tabular}{|c|c|c|c|c|c|c|c|}
\hline Model & Intercept & Slope & Variable & coefficient & Standard deviation & t-student & P-value \\
\hline \multirow[b]{2}{*}{3} & \multirow[b]{2}{*}{ Pooled } & \multirow{2}{*}{$\begin{array}{l}\text { Panel \& } \\
\text { fixed effect }\end{array}$} & $\mathrm{C}$ & 0.026934 & 0.005461 & 4.932375 & 0.0000 \\
\hline & & & INSOWN & 0.001325 & 0.000598 & 2.215542 & 0.0300 \\
\hline \multirow[b]{2}{*}{4} & \multirow[b]{2}{*}{ Pooled } & Panel \& & $\mathrm{C}$ & 0.009038 & 0.016646 & 0.542934 & 0.5889 \\
\hline & & Random effect & SH5 & 0.007638 & 0.005591 & 1.366225 & 0.1762 \\
\hline \multirow[b]{2}{*}{5} & \multirow[b]{2}{*}{ Pooled } & Panel \& & $\mathrm{C}$ & 0.041134 & 0.012328 & 3.336654 & 0.0014 \\
\hline & & Random effect & OWNCON & -0.001996 & 0.001430 & -1.395545 & 0.1673 \\
\hline \multirow[b]{2}{*}{6} & \multirow[b]{2}{*}{ Pooled } & Panel \& & $\mathrm{C}$ & 0.021519 & 0.006142 & 3.503557 & 0.0008 \\
\hline & & Random effect & BSIZE & 0.009910 & 0.005929 & 1.671439 & 0.0991 \\
\hline \multirow[b]{2}{*}{7} & \multirow[b]{2}{*}{ Pooled } & Panel \& & $\mathrm{C}$ & 0.056974 & 0.022542 & 2.527473 & 0.0137 \\
\hline & & Random effect & DEBTRL & -0.005640 & 0.004334 & -1.301368 & 0.1974 \\
\hline \multirow[b]{2}{*}{8} & \multirow{2}{*}{$\begin{array}{l}\text { Pannel } \\
\text { effect }\end{array}$} & Pooled & $\mathrm{C}$ & 0.023927 & 0.006183 & 3.869774 & 0.0002 \\
\hline & & & LSIZE & 0.327855 & 0.342934 & 0.956031 & 0.3423 \\
\hline \multirow{3}{*}{9} & \multirow[b]{2}{*}{ Pooled } & Panel \& & $\mathrm{C}$ & 0.024998 & 0.008820 & 2.834320 & 0.0060 \\
\hline & & Random effect & ROA & 0.000965 & 0.000967 & 0.997915 & 0.3218 \\
\hline & \multirow[b]{2}{*}{ Pooled } & Panel \& & $\mathrm{C}$ & 0.026934 & 0.005461 & 4.932375 & 0.0000 \\
\hline 10 & & Random effect & $\mathrm{CFO}$ & 0.001325 & 0.000598 & 2.215542 & 0.0300 \\
\hline
\end{tabular}

From the results of Table 8, it is clear that only the effect of institutional ownership is statistically meaningful and the other factors have no influence on earning quality.

In summary, we have realized that, among different factors, the effect of big five shareholder are considered to be significant and positive on earning quality. In addition, the effect of one variable test reveals that institutional ownership has positive impact on earning quality. However, the impacts of other variables including percentage of ownership concentration, the size of board of directors, reliance on debt, logarithm of sum of assets, return of assets, logarithm of operating cash flow on earning quality are not meaningful. The result of this survey indicates that institutional ownership plays an important role earning quality simply because institutions normally have the access on professionals to control management.

\section{Conclusion}

In this paper, we have presented an empirical study to analysis the effects of different factors on earning quality. The proposed study has gathered the necessary information for different Iranian private banks from 2005 to 2010 and analyzed the results using different regression functions. Table 9 summarizes the findings of the results.

\section{Table 9}

The summary of the impact of eight independent variables on earning quality

\begin{tabular}{clccc}
\hline Hypothesis & Item & Using independent variable & $\begin{array}{c}\text { Using independent } \\
\text { variable \& Control }\end{array}$ & $\begin{array}{c}\text { Single } \\
\text { variable }\end{array}$ \\
\hline 1 & Ownership concentration & $\times$ & $\times$ & $\times$ \\
\hline 2 & Institutional ownership & $\times$ & $\times$ & $\sqrt{ }$ \\
\hline 3 & Size of board of directors & $\times$ & $\sqrt{ }$ & $\times$ \\
\hline 4 & Big five shareholders & $\sqrt{ }$ & $\times$ \\
\hline 5 & Debt ratio & & $\times$ & $\times$ \\
\hline 6 & Operating cash flow & & $\times$ & $\times$ \\
\hline 7 & Return on assets & & $\times$ & $\times$ \\
\hline 8 & Bank size & & $\times$ & $\times$ \\
\hline
\end{tabular}

Base on the results of Table 9, we have realized that, among different factors, the effect of big five shareholder are considered to be significant and positive on earning quality. In addition, the effect of 
one variable test reveals that institutional ownership has positive impact on earning quality. However, the impacts of other variables including percentage of ownership concentration, the size of board of directors, reliance on debt, logarithm of sum of assets, return of assets, logarithm of operating cash flow on earning quality are not meaningful. The result of this survey indicates that institutional ownership plays an important role earning quality simply because institutions normally have the access on professionals to control management.

\section{Acknowledgment}

The authors would like to thank the anonymous referees for their constructive comments on earlier version of this paper.

\section{References}

Ashbaugh-Skaife, H., Collins, D., Kinney, W., \& LaFond, R. (2008). The effect of SOX internal control deficiencies and their remediation on accrual quality. Accounting Review, 83, 217250.

Ball, R., \& Shivakumar, L. (2008). Earnings quality at initial public offerings. Journal of Accounting and Economics, 45,324-349.

Bozec, Y., \& Laurin, C. (2008). Large shareholder entrenchment and performance: Empirical evidence from Canada. Journal of Finance \& Accounting, 35, 25-49.

Cain, A. C., Kolev, K., \& Mc Vay, S. (2009). A comprehensive analysis of the use of special items to manage earnings. Working Paper, Purdue University.

Dechow, P. M., \& Shrand, C. M. (2004). Earning Quality, $1^{\text {st }}$ ed., United States of America: Research Foundation of CFA Institute.

Dechow, P. M., \& Ge, W. (2005). The persistence of earnings and cash flows and the role of special items, implications for the accrual anomaly. Working Paper, 1-61, ssrn.com.

Dechow, P., W. Ge., \& Schrand, C. (2009). Understanding earnings quality: A review of the proxies, their determinants and their consequences. Journal of Accounting and Economics, 50, 344-401

Dogan, M., Coskun, E., \& Cekik, O. (2007). Is timing of financial reporting related to firm performance? An examination of ISE listed companies. International Research Journal of Finance and Economics, 12, 220-223.

Francis, J., LaFond, R., Olsson, P., \& Schipper, K. (2004). Cost of equity and earnings attributes. The Accounting Review, 79, 967-1010.

Francis, J., \& Micheal, S. (2005). A reexamination of the persistence of accruals and cash flows. Journal of Accounting and Economics, 43(3), 413-451.

Haidar, J. I. (2009). Investor protections and economic growth. Economics Letters, 103(1), 1-4.

Huang, P., Zhang, Y., Deis, D. R., \& Moffitt, J. S. (2009). Do artificial income smoothing and real income smoothing contribute to fair value equivalently? Journal of Banking and Finance, 33,224-233.

Scott, A., Sloan, R., Soliman, M., \& Tuna, I. (2005). Accrual reliability, earnings persistence and stock returns. Journal of Accounting Research, 39, 437-485. 